\title{
The use of diode lasers in non-surgical therapy of periodontitis
}

\author{
Małgorzata Majka Kulińska-Michalska ${ }^{1, A-D \oplus}$, Natalia Ćwiklińska ${ }^{1, B, D \oplus}$, Magda Lisiecka $^{1, A \oplus}$, \\ Patrycja Czaplicka-Szydlik ${ }^{1, A}{ }^{\oplus}$, Natalia Lewkowicz ${ }^{1, A, E-F} \odot$ \\ ${ }^{1}$ Departament of Periodontology and Oral Disease, Medical University, Łódź, Poland \\ A - Research concept and design, B - Collection and/or assembly of data, C - Data analysis and interpretation, \\ $D$ - Writing the article, E - Critical revision of the article, F - Final approval of article
}

\begin{abstract}
Kulińska-Michalska MM, Ćwiklińska N, Lisiecka M, Czaplicka-Szydlik P, Lewkowicz N. The use of diode lasers in non-surgical therapy of periodontitis. J Pre-Clin Clin Res. 2020; 14(4): 169-173. doi: 10.26444/jpccr/131040
\end{abstract}

\begin{abstract} more popular. combination with laser irradiation of periodontal pockets. therapy or SRP with laser irradiation, compared to an SRP alone. treatment.

I Key words

aPDT, PDT, periodontal treatment, photodynamic therapy, SRP
\end{abstract}

Introduction. Periodontitis is a disease of multifactorial etiology and complex clinical manifestation. Removal of subgingival bacterial biofilm is a fundamental procedure in the treatment of periodontitis. Scaling and root planing (SRP) is currently the gold standard in the treatment of periodontitis, but in some cases such a procedure does not provide satisfactory results. The use of lasers in the treatment of periodontitis is one of the alternative adjunctive methods that has recently become

Objective. The aim of the study was to evaluate the effectiveness of diode lasers in the treatment of periodontitis, based on the literature found in the Medline, Pubmed and Scopus databases published from June 2013 - June 2020. Results were based on a comparison of the effectiveness of SRP treatment in combination with photodynamic therapy or SRP in

Results. The majority of studies confirmed the effectiveness of periodontal treatment combining SRP with photodynamic

Conclusions. Based on the recent literature, it can be concluded that SRP combined with photodynamic therapy or SRP in combination with a diode laser irradiation are effective methods to improve the outcomes of non-surgical periodontal

\section{INTRODUCTION}

Periodontitis is an inflammatory disease that affects tooth-supporting tissues [1]. The etiology of periodontitis is complex, involving primarily the interplay between subgingival bacterial biofilm and the immune response of the host. Symptoms of periodontitis depend on the interaction between environmental and genetic factors. Pro-inflammatory mediators (IL-1, IL-6, TNF) released in response to Gram-negative bacteria (periopathogens) present in subgingival biofilm, trigger inflammation in periodontal tissues [2]. The progressive disease process leads to the destruction of tooth-supporting tissues, and, consequently, tooth loss [3].

Scaling and root planing (SRP) is a basic procedure in the treatment of periodontitis that aims at the removal of the subgingival biofilm. SRP results in the resolution of inflammation and healing of periodontal pockets, mainly by formation of a long epithelial junction. Clinical effectiveness of this technique is well-documented and nowadays SRP is the 'gold standard' in the treatment of periodontitis $[4,5]$. Unfortunately, sometimes clinical improvement is insufficient, which may result from local conditions, such as pocket depth or tooth furcation area, as the accuracy of subgingival instrumentation decreases with the increase of

Address for correspondence: Małgorzata Majka Kulińska, Departament of Periodontology and Oral Disease, Michalska Medical University, Pomorska 251, 92-213 Łódź, Poland

E-mail: malgorzatakulinskam@gmail.com

Received: 14.10.2020; accepted: 30.11.2020; first published: 28.12.2020 the probing depth (PD) $[6,7]$. An additional problem is the increasing resistance of subgingival microorganisms to the antimicrobials used locally or systemically as an adjunct to SRP. These factors contributed to the need for alternative methods in the non-surgical treatment of periodontitis.

The use of lasers has been reported for many years as a method complementary to standard procedures in the treatment of periodontitis [8]. However, there is still much controversy about their effectiveness. Diode lasers with a wavelength of 630-690 nm, $805 \mathrm{~nm}, 808-810 \mathrm{~nm}$, can be used for antibacterial photodynamic therapy (aPDT), while diode lasers with a wavelength of $940 \mathrm{~nm}$ or $980 \mathrm{~nm}$ are used in bacterial decontamination, soft tissue curettage in periodontal pockets, and photobiomodulation therapy.

\section{OBJECTIVE}

The aim of this review article was to evaluate the effectiveness of he diode lasers in the treatment of periodontitis, based on the literature found in the Medline, Pubmed and Scopus databases published over the last seven years. Taken into into account were the research studies that analysed the effectiveness of SRP treatment in combination with photodynamic therapy or SRP in combination with laser irradiation of periodontal pockets, in comparison to SRP alone. Databases were searched by using the following keywords: 'diode laser and periodontitis', 'diode laser and periodontal therapy', 'photodynamic therapy and periodontitis'. 
Antimicrobial photodynamic therapy. Antimicrobial photodynamic therapy is a form of phototherapy that utilizes light and a photosensitizer used in conjunction with molecular oxygen to cause cell death. In periodontal treatment, it aims to reduce the number of periopathogens. A photosensitizer is activated by an appropriate light length emitted by a low power laser $630-690 \mathrm{~nm}$ or a light emitting diode (LED) lamp. Toluidine blue is the most commonly used photosensitizer in the treatment of periodontitis, this is due to high effectiveness against Gram (-) and (+) bacteria [9, 10]. Depending on the oxygen availability in the environment and the photosensitizer used, two types of reactions can occur. At low oxygen concentrations, free radicals are formed, i.e.superoxide radical $(\mathrm{O} 2)$, hydroxyl radical $(\mathrm{OH})$, hydroxide radical $(\mathrm{HO} 2)$ and hydrogen peroxide $(\mathrm{H} 2 \mathrm{O} 2)$ which destroy cell membranes, enzymes and DNA (9). In an oxygen-rich environment, singlet oxygen is formed which contributes to the increased permeability of bacterial cell membranes mediating cell death. When using toluidine blue as a photosensitizer, the second type of reaction is primarily induced [9]. Single deep periodontal pockets $(>5 \mathrm{~mm})$ which did not react properly to mechanical instrumentation are the indication for the use of aPDT in periodontal treatment (1). An additional benefit of using aPDT is the lack of adverse effects on dentine, pulp and alveolar bone [11].

Several studies analysing the effectiveness of non-surgical treatment supplemented with photodynamic therapy were found during the database serach (Tab. 1). It was shown that application of aPDT as supportive treatment had a beneficial effect on both clinical and microbiological parameters. The improvement was observed in the probing depth (PD), clinical attachment level (CAL), gingival index (GI) and bleeding on probing (BOP) levels, but there was also a reduction in the number of periodontal bacteria A. actinomycetemcomitans, T. forsythia, P. gingivalis $[12,13,14,15]$. A very recent randomized clinical trial in 2020 showed significant improvement of PD and CAL after aPDT, in comparison to SRP alone [16]. It was also demonstrated that SRP plus aPDT

Table 1. The use of PDT in the treatment of periodontitis - a summary of clinical studies

\begin{tabular}{|c|c|c|c|c|c|c|}
\hline Author & Type of study & $\begin{array}{l}\text { Study } \\
\text { groups }\end{array}$ & $\begin{array}{l}\text { Study } \\
\text { outcomes }\end{array}$ & $\begin{array}{l}\text { Study } \\
\text { duration }\end{array}$ & Laser parameters & Results \\
\hline $\begin{array}{l}\text { Balata et al. } \\
2013(22)\end{array}$ & $\begin{array}{l}\text { Randomized control } \\
\text { clinical trial }\end{array}$ & $\begin{array}{l}22 \text { patients } \\
\text { aged } 31-62\end{array}$ & $\begin{array}{l}\text { PD, BOP, } \\
\text { CAL }\end{array}$ & 6 months & $\begin{array}{l}\text { Diode laser } 660 \mathrm{~nm} \text {, methylene } \\
\text { blue }\end{array}$ & $\begin{array}{l}\text { No significant benefits of aPDT in comparison } \\
\text { to patients who receive full-mouth ultrasonic } \\
\text { debridement alone compared to SRP alone }\end{array}$ \\
\hline $\begin{array}{l}\text { Arweiler et al. } \\
2013(24)\end{array}$ & $\begin{array}{l}\text { Randomized control } \\
\text { clinical study }\end{array}$ & $\begin{array}{l}36 \text { patients } \\
\text { aged } 23-55\end{array}$ & $\begin{array}{l}\mathrm{PD}, \mathrm{CAL} \\
\mathrm{BOP}, \mathrm{PI}\end{array}$ & 3 months & $\begin{array}{l}\text { Diode laser } 660 \mathrm{~nm} \text {, } \\
\text { phenothiazine } \\
\text { chloride }\end{array}$ & $\begin{array}{l}\text { Larger number of residual pockets after treatment } \\
\text { in aPDT in comparison to patients who receive } \\
\text { systemic antibiotic treatment }\end{array}$ \\
\hline $\begin{array}{l}\text { Chitsazi et al. } \\
2015(21)\end{array}$ & $\begin{array}{l}\text { Ramdomized clinical } \\
\text { study }\end{array}$ & 24 patients & PD, BOP & 3 months & $\begin{array}{l}\text { Diode laser } 670-690 \mathrm{~nm} \text {, a power } \\
\text { of } 75 \mathrm{~mW} \text {, toluidine blue }\end{array}$ & $\begin{array}{l}\text { No statistically significant improvement in PD after } \\
\text { treatment aPDT as compared to SRP alone }\end{array}$ \\
\hline $\begin{array}{l}\text { Skurska et al. } \\
2015 \text { (25) }\end{array}$ & $\begin{array}{l}\text { Randomized clinical } \\
\text { trial }\end{array}$ & $\begin{array}{l}36 \text { patients } \\
\text { aged } \\
30-60\end{array}$ & $\begin{array}{l}\text { Levels of } \\
\text { MMP-8 and } \\
\text { MMP-9 in GCF }\end{array}$ & 6 months & $\begin{array}{l}\text { Diode laser } 660 \mathrm{~nm}, \mathrm{HELBO}^{\oplus} \text { Blue } \\
\text { Photosensitizer }\end{array}$ & $\begin{array}{l}\text { Significant decrease of MMP8 and MMP9 in } \\
\text { patients who additionally received systemic } \\
\text { antibiotic therapy compared to SRP + aPDT }\end{array}$ \\
\hline $\begin{array}{l}\text { Kastriot Meqa } \\
\text { et al. } 2016 \\
\text { (12) }\end{array}$ & $\begin{array}{l}\text { Randomized double- } \\
\text { blind prospective } \\
\text { study }\end{array}$ & $\begin{array}{l}50 \text { patients } \\
\text { aged } \\
20-50\end{array}$ & $\begin{array}{l}\mathrm{PD}, \mathrm{CAL}, \mathrm{GR}, \\
\mathrm{Gl}, \mathrm{BOP}\end{array}$ & 2 months & $\begin{array}{l}\text { Diode laser } 660 \mathrm{~nm} \text {, power of } 100 \\
\mathrm{~mW} \text {, phenothiazine chloride }\end{array}$ & $\begin{array}{l}\text { Greater improvement in PD, CAL, GI and BoP } \\
\text { parameters using aPDT compared to SRP alone }\end{array}$ \\
\hline $\begin{array}{l}\text { Sheedhar } \\
\text { Annaji et al. } \\
2016(14)\end{array}$ & $\begin{array}{l}\text { Randomized clinical } \\
\text { trial, split-mouth } \\
\text { design study }\end{array}$ & $\begin{array}{l}15 \text { patients } \\
\text { aged } \\
18-35\end{array}$ & $\begin{array}{l}\text { PI, BOP, PD, } \\
\text { RAL }\end{array}$ & 3 months & $\begin{array}{l}\text { Diode laser } 810 \mathrm{~nm} \text {, toluidine } \\
\text { blue } 1 \mathrm{mg} / \mathrm{ml}\end{array}$ & $\begin{array}{l}\text { With increase of treatment time, the highest } \\
\text { decrease in the periodontal indicators (PI, PD, } \\
\text { BOP) compared to SRP alone and SRP + diode } \\
\text { laser }\end{array}$ \\
\hline $\begin{array}{l}\text { Abbas } \\
\text { Monzavi et al. } \\
2016(13)\end{array}$ & $\begin{array}{l}\text { Ramdomized clinical } \\
\text { trial }\end{array}$ & $\begin{array}{l}50 \text { patients } \\
\text { aged }>35\end{array}$ & $\begin{array}{l}\text { PD, BOP, CAL, } \\
\text { PI, FMBS, } \\
\text { FMPS }\end{array}$ & 3 months & $\begin{array}{l}\text { Diode laser } 810 \mathrm{~nm} \text {, a power of } \\
200 \mathrm{~mW} \text {, indometacin green }\end{array}$ & $\begin{array}{l}\text { Combining SRP and aPDT results in a significant } \\
\text { improvement in PD, BOP and FMBS in comparison } \\
\text { to SRP alone }\end{array}$ \\
\hline $\begin{array}{l}\text { Vohra et al. } \\
2018 \text { (18) }\end{array}$ & $\begin{array}{l}\text { Randomized control } \\
\text { clinical trial }\end{array}$ & 53 patients & $\begin{array}{l}\mathrm{BOP}, \mathrm{CAL}, \mathrm{PD}, \\
\mathrm{PI}, \mathrm{GCF}\end{array}$ & 12 weeks & $\begin{array}{l}\text { Diode laser } 670 \mathrm{~nm} \text {, methylene } \\
\text { blue }\end{array}$ & $\begin{array}{l}\text { Significant improvement in clinical and } \\
\text { immunological parameters after treatment with } \\
\text { aPDT and SRP compared to SRP alone }\end{array}$ \\
\hline $\begin{array}{l}\text { Soares et al. } \\
2019(23)\end{array}$ & $\begin{array}{l}\text { Randomized clinical } \\
\text { trial, split-mouth } \\
\text { design study }\end{array}$ & $\begin{array}{l}20 \text { patients } \\
\text { aged } 39-61\end{array}$ & $\begin{array}{l}\mathrm{BOP}, \mathrm{CAL}, \mathrm{PD}, \\
\mathrm{PI}, \mathrm{GCF}\end{array}$ & 90 days & $\begin{array}{l}\text { Diode laser } 660 \mathrm{~nm} \text {, a power of } 70 \\
\mathrm{~mW} \text {, phenothiazine chloride }\end{array}$ & $\begin{array}{l}\text { Combining SRP and aPDT did not promote } \\
\text { additional clinical, immunological, and } \\
\text { microbiological benefits in smokers with chronic } \\
\text { periodontitis compared to SRP alone }\end{array}$ \\
\hline $\begin{array}{l}\text { Deumer et al. } \\
2019 \text { (19) }\end{array}$ & $\begin{array}{l}\text { Randomized clinical } \\
\text { trial, split-mouth } \\
\text { design study }\end{array}$ & $\begin{array}{l}20 \text { patients } \\
\text { aged } 30-70\end{array}$ & $\begin{array}{l}\text { aMMP-8 in } \\
\text { GCF, PD, BOP }\end{array}$ & 4 weeks & $\begin{array}{l}\text { Diode laser } 820 \mathrm{~nm} \text {, a power } \\
\text { between } 200 \text { and } 300 \mathrm{nW} \text {, } \\
\text { photothermic dye was } \\
\text { infracyaningreen }\end{array}$ & $\begin{array}{l}\text { Larger decrease of the aMMP- } 8 \text { and PD after } \\
\text { treatment with aPTD in comparison to control } \\
\text { group }\end{array}$ \\
\hline $\begin{array}{l}\text { Al Habashneh } \\
\text { et al. } 2019 \\
\text { (20) }\end{array}$ & $\begin{array}{l}\text { Randomized clinical } \\
\text { trial, split-mouth } \\
\text { design study }\end{array}$ & $\begin{array}{l}16 \text { patients } \\
\text { aged } 30-60\end{array}$ & $\begin{array}{l}\text { PI, GR, BOP, } \\
\text { PD, CAL, IL-1 } \beta \\
\text { level in GCF }\end{array}$ & 6 months & $\begin{array}{l}\text { Red LED light system of } \\
\text { wavelength of } 635 \mathrm{~nm} \text {, toluidine } \\
\text { blue }\end{array}$ & $\begin{array}{l}\text { Significant improvement after SRP }+ \text { aPTD of } \\
\text { clinical parameters, } \\
\text { aPTD treatment had no effects on the level of } \\
\text { expression of IL- } 1 \beta \text { compared to SRP alone }\end{array}$ \\
\hline $\begin{array}{l}\text { Joshi et al. } \\
2020 \text { (16) }\end{array}$ & $\begin{array}{l}\text { Randomized clinical } \\
\text { trial }\end{array}$ & $\begin{array}{l}29 \text { patients } \\
\text { aged } 30-60\end{array}$ & $\begin{array}{l}\text { PI, mSBI, PD, } \\
\text { CAL }\end{array}$ & 3 months & $\begin{array}{l}\text { Diode laser with wavelength } \\
\text { of } 810 \mathrm{~nm} \text {, power } 0.2 \mathrm{~W} \text { with } \\
\text { indocyanine green } 1 \mathrm{mg} / \mathrm{ml}\end{array}$ & $\begin{array}{l}\text { Significant reduction in clinical parameters } \\
\text { (PI, mSBI, PD, CAL) in both groups, statistically } \\
\text { significant improvement in PD and CAL after SRP } \\
+ \text { aPDT compared to SRP alone }\end{array}$ \\
\hline
\end{tabular}


resulted in the decrease of BoP, gingival pain and halitosis in comparison to SRP alone, but the difference was only short-term [17]. Vohra et al. showed significant improvement in clinical and immunological parameters in obese patients with chronic periodontitis after treatment with SRP and aPDT, compared to SRP alone [18]. The study performed by Deumer et al. showed a higher decrease of the MMP-8 in GCF, and statistically significant improvement in PD after aPDT application, compared to SRP alone [19]. Another clinical study showed improvement of clinical parameters after SRP and aPDT treatment, but no effects on the levels of IL-1 $1 \beta$ was observed [20]. In contrast to these studies, others failed to demonstrate any statistically significant microbiological or clinical periodontal improvement when aPDT was additionally used with SRP in comparison to SRP alone $[21,22]$. Also, Soares et al. confirmed no statistically significant immunological, microbiological or clinical periodontal improvement after combining SRP and aPDT in smokers with chronic periodontitis [23]. SRP supplemented with aPDT in patients with aggressive periodontitis resulted Ina higher number of residual periodontal pockets after treatment, in comparison to systemic antibiotic therapy [24], and a lower decrease in the MMP8 and MMP9 in gingivocrevicular fluid (GCF) [25]. aPDT can also be used in the treatment of peri-implantitis with toluidine blue as a photosensitizer [1]. A clinical study showed a greater reduction of periopathogens around implants affected by peri-implantitis in the patients who underwent aPDT [26]. Several studies also confirmed the positive effect of aPDT on osseointegration as an additional procedure in the GBR technique [27].

Laser therapy. Laser irradiation is one of the methods that can supplement the mechanical debridement of the root surface in the treatment of periodontitis. Some types of lasers can be used as an alternative monotherapy for conventional treatments (Er:YAG, Er,Cr:YSSG), or as adjunctive therapy in combination with SRP (Nd:YAG, diode laser). The combination of Er;YAG and Nd;YAG lasers gives significant improvement in clinical parameters; additionally, considerable reduction of bacteria are demonstrated after connection Nd:YAG laser with oxidative disinfectant $(0.5 \%$ $\mathrm{NaOCl}$ or $\mathrm{H} 2 \mathrm{O} 2)[28,29,30]$. Research has shown notable reductions in Candida albicans and Streptococcus mutans and their metabolism after Nd:YAG laser irradiation [31]. Diode lasers in periodontology can also be used for gingivectomy/gingivoplasty of hypertrophic gingiva. A high relief of pain was also confirmed in orthodontic treatmen of patients after application of a diode laser with wavelength $635 \mathrm{~nm}$ [34]. Photobiomodulation (PBM) is especially indicated in the treatment of patients at risk of bacteremia or with immune deficiency [28]. The advantages of using lasers in the treatment of periodontitis include bactericidal effect and photobiomodulation that results in local reduction of periopathogens, reduction of post-operative pain and swelling, reduced amount of anaesthetics during the procedure, as well as a reduced need for pharmacological treatment after procedure $[28,29]$. In addition, the use of the laser improves access to the deep and narrow periodontal pockets, the bi- and tri-furcation area, and increases the visibility in the operating area by reducing bleeding.

Several studies have been performed to assess the effectiveness of diode laser irradiation in the treatment of periodontitis (Tab. 2). As clinical trials differed in terms of the study design, the wavelength of the laser and method of application, different results were obtained. Some studies showed that the additional use of a diode laser $980 \mathrm{~nm}$ provided statistically significant benefits in terms of clinical parameters $\mathrm{PD}, \mathrm{BOP}$ and CAL, and a decrease in the number of periopathogens A. actinomycetemcomitans and $\mathrm{P}$. gingivalis, in comparison to SRP alone $[13,33,35,36$, 37]. Another study confirmed that the highest $P D$ reduction was observed after the use of SR, in comparison to diode laser decontamination and SRP alone [38]. Only one clinical study showed no clinical difference when LLLT was additional used with SRP in comparison to SRP alone [39]. It was also demonstrated that non-surgical treatment, additionally supplemented with low energy laser irradiatio, produced better results than SRP due to the photobiomodulation effect. LLLT can be used as an effective SRP support therapy helping to improve clinical parameters and promote resolution of inflammation $[14,40,41,42]$. It was shown that a combination of Er, Cr: YSGG (2780 nm) laser used for pocket debridement, followed by a diode laser $(940 \mathrm{~nm})$, resulted in a statistically significant improvement in PD and a faster remineralization of bone defects [43]. Another clinical study demonstrated that in e patients with chronic periodontitis and type II diabetes treated with LLLT, a significant improvement in BOP and PD was achieved [44]. Photoactivation of hydrogen peroxide with $940 \mathrm{~nm}$ diode laser is a newly-described method [45]. A pilot study demonstrated statistically significant antimicrobial and clinical effects when SRP was followed by laser irradiation, especially in the presence of $3 \%$ hydrogen peroxide in the treated pockets. Together, these results suggest that diode laser irradiation is an effective type of therapy supporting SRP and helping to obtain better outcomes, compared to SRP alone.

\section{CONCLUSIONS}

Based on literature from the last seven years, it can be concluded that SRP combined with photodynamic therapy or SRP in combination with a diode laser irradiation are effective methods to improve the outcomes of non-surgical periodontal treatment. Among the analysed works, only two out of eleven did not confirm the effectiveness SRP in combination with diode laser; for comparison, five out of thirteen analysed works did not confirm the effectiveness of SRP in combination with aPDT. PBM resulted in a significant decrease of periopathogenes and an additional reduction of periodontal pocket depth. The use of the diode laser in periodontal treatment is a method that supports conventional non-surgical therapy. The advantages of using lasers in the treatment of periodontitis include bactericidal effect, photobiomodulation, reduction of post-surgical pain and swelling. An additional benefit of laser therapy is the high acceptance by patients. Safety of use and potential benefits of laser therapy encourage its use in various areas of dentistry. However, it is worth mentioning that the European Federation of Periodontology (EFP) at present does not recommend the routine use of lasers as adjuncts to subgingival instrumentation, based on the five RCTs ( $\mathrm{n}=$ 121 , wavelength range $660-670 \mathrm{~nm}$ and $800-900 \mathrm{~nm}$ ), with single aPDT application reporting 6-month outcomes [46]. The quality of evidence in this area is still low, mainly due to 
Table 2. The effectiveness of diode laser irradiation in the treatment of periodontitis - a summary of clinical studies

\begin{tabular}{|c|c|c|c|c|c|c|}
\hline Author & Type of study & $N$ & Studied parameters & Duration & Laser parameters & Results \\
\hline $\begin{array}{l}\text { Mirjana Gojkov- } \\
\text { Vukelic et al. } 2013 \\
\text { (33) }\end{array}$ & $\begin{array}{l}\text { Randomized } \\
\text { clinical trial }\end{array}$ & 24 & $\begin{array}{l}\text { Microbiological } \\
\text { assessment of the number } \\
\text { of bacteria }\end{array}$ & $3 \mathrm{mo}$ & $\begin{array}{l}\text { Diode laser } 980 \mathrm{~nm} \text {, a power of } \\
2.0 \mathrm{~W}, 5 \mathrm{sec} \text { per site, inside the } \\
\text { pocket }\end{array}$ & $\begin{array}{l}\text { Significant decrease in periopathogenes after } \\
\text { LLLT compared to SRP alone }\end{array}$ \\
\hline $\begin{array}{l}\text { Üstün et al. } 2014 \\
\text { (40) }\end{array}$ & $\begin{array}{l}\text { Randomized } \\
\text { clinical trial, split- } \\
\text { mouth design } \\
\text { study }\end{array}$ & 21 & $\begin{array}{l}\text { Clinical parameters and } \\
\text { IL-1 } \beta \text { level in the gingival } \\
\text { fluid }\end{array}$ & $6 \mathrm{mo}$ & $\begin{array}{l}\text { Diode laser } 810 \mathrm{~nm} \text {, a power of } \\
2,5 \mathrm{~W} \text {, pulsed mode }\end{array}$ & $\begin{array}{l}\text { Greater improvement in clinical parameters } \\
\text { and IL-1 } \beta \text { level in the gingival fluid after LLLT } \\
\text { compared to SRP alone }\end{array}$ \\
\hline $\begin{array}{l}\text { Kachapilly et } \\
\text { al.2016 (38) }\end{array}$ & Clinical study & 15 & $\mathrm{PI}, \mathrm{GI}, \mathrm{PD}, \mathrm{CAL}$ & $3 \mathrm{mo}$ & $\begin{array}{l}\text { Diode laser } 810 \mathrm{~nm} \text {, a power of } \\
0.5 \mathrm{~W}, 10 \mathrm{sec} \text { per site, inside the } \\
\text { pocket }\end{array}$ & $\begin{array}{l}\text { Additional use of LLLT after SRP did not } \\
\text { provide any significant clinical improvement } \\
\text { compared to SRP alone }\end{array}$ \\
\hline $\begin{array}{l}\text { Suryakanth } \\
\text { Malgikar } \\
\text { et al.2016 (37) }\end{array}$ & $\begin{array}{l}\text { Randomized } \\
\text { controlled clinical } \\
\text { trial, split-mouth } \\
\text { design study }\end{array}$ & 24 & $\mathrm{PI}, \mathrm{Gl}, \mathrm{mSBI}, \mathrm{PD}, \mathrm{CAL}$ & $6 \mathrm{mo}$ & $\begin{array}{l}\text { Diode laser } 980 \mathrm{~nm} \text {, non-contact } \\
\text { use at the gingival margin at a } \\
\text { distance of approximate } 1-2 \mathrm{~mm} \text {, } \\
1.5 \mathrm{~W} \text {, continuous wave }\end{array}$ & $\begin{array}{l}\text { Improvement in clinical parameters with LLLT } \\
\text { compared to SRP alone }\end{array}$ \\
\hline $\begin{array}{l}\text { Meseli et al. } 2017 \\
\text { (39) }\end{array}$ & $\begin{array}{l}\text { Randomized } \\
\text { clinical trial }\end{array}$ & 11 & $\begin{array}{l}\mathrm{PI}, \mathrm{PD}, \mathrm{CAL}, \mathrm{BOP}, \mathrm{GCF} \\
\text { volume }\end{array}$ & $\begin{array}{l}19 \\
\text { weeks }\end{array}$ & $\begin{array}{l}\text { Diode laser } 810 \mathrm{~nm}, 1 \mathrm{~W} \text {, inside } \\
\text { the pocket }\end{array}$ & $\begin{array}{l}\text { LLLT as an adjunct to mechanical treatment } \\
\text { have no additional effects on clinical } \\
\text { parameters and GCF volume compared to } \\
\text { SRP alone }\end{array}$ \\
\hline $\begin{array}{l}\text { Demirturk- } \\
\text { Gocgun et al. } \\
2017 \text { (44) }\end{array}$ & $\begin{array}{l}\text { Randomized } \\
\text { controlled clinical } \\
\text { trial, split-mouth } \\
\text { design study }\end{array}$ & 22 & $\mathrm{PI}, \mathrm{PD}, \mathrm{BOP}, \mathrm{CAL}$ & $\begin{array}{l}3 \\
\text { mo }\end{array}$ & Diode laser $808 \mathrm{~nm}, 4.46 \mathrm{~J} / \mathrm{cm} 2$ & $\begin{array}{l}\text { Use of LLLT brings additional benefit in the } \\
\text { treatment of deep pockets compared to SRP } \\
\text { alone }\end{array}$ \\
\hline $\begin{array}{l}\text { Petrović et al. } \\
2018 \text { (35) }\end{array}$ & $\begin{array}{l}\text { Randomized } \\
\text { clinical trial }\end{array}$ & 60 & $\begin{array}{l}\text { Microbiological and clinical } \\
\text { assessment, CAL, BI, PI }\end{array}$ & $1 \mathrm{mo}$ & $\begin{array}{l}\text { Diode lasers } 980 \mathrm{~nm}, 0.2 \mathrm{~W}, 6 \mathrm{~J} / \\
\mathrm{cm} 2\end{array}$ & $\begin{array}{l}\text { LLLT as an adjunct to periodontal therapy } \\
\text { demonstrates additional bacteriological, } \\
\text { cytological and clinical benefits compared to } \\
\text { SRP alone }\end{array}$ \\
\hline $\begin{array}{l}\text { Chandra and } \\
\text { Shashikumar } 2019 \\
\text { (41) }\end{array}$ & $\begin{array}{l}\text { Randomized } \\
\text { control clinical } \\
\text { trial }\end{array}$ & 36 & $\begin{array}{l}\mathrm{PI}, \mathrm{Gl}, \mathrm{CAL}, \mathrm{PD}, \mathrm{HbA} 1 \mathrm{c} \\
\text { colony count of } A . a . \text { and } \\
\text { P.g. }\end{array}$ & $3 \mathrm{mo}$ & $\begin{array}{l}\text { Diode laser } 808 \mathrm{~nm}, 1.5-1.8 \mathrm{~W} \text {, } \\
\text { continuous wave }\end{array}$ & $\begin{array}{l}\text { Statistically significant improvement in clinical } \\
\text { and microbiological parameters after LLLT } \\
\text { compared to SRP alone }\end{array}$ \\
\hline $\begin{array}{l}\text { Manjunath et al. } \\
2020 \text { (36) }\end{array}$ & $\begin{array}{l}\text { Randomized } \\
\text { clinical trial }\end{array}$ & 40 & $\mathrm{OHI}, \mathrm{CAL}, \mathrm{PD}, \mathrm{BOP}$ & $\begin{array}{l}12 \\
\text { weeks }\end{array}$ & Diode laser $980 \mathrm{~nm}, 2.0 \mathrm{~W}$ & $\begin{array}{l}\text { Significant decrease in clinical parameters } \\
\text { after LLLT compared to SRP alone }\end{array}$ \\
\hline
\end{tabular}

PD - probing depth; BOP - bleeding of probing; PI - plaque index; $\mathrm{mSBI}$ - modified sulcus bleeding index' CAL - clinical attachment level; GCF - gingival crevicular fluid; GI - gingival index; $\mathrm{BI}$ - bleeding index; $\mathrm{OHI}$ - oral hygiene index; IL-1 $\beta$ - interleukine 1B; IL-37 - interleukine 37; HbA1c - haemoglobin A1c; A.a. - Aggregatibacter actinomycetemcomitans; P.g. - Porphyromonas gingivalis; T.f. - Tanerella forsythia; T.d. - Treponema denticola; P.i. - Prevotella intermedia; P.m. - Peptostreptococcus micros; F.n. - Fusobacterium nucleatum; E.n. - Eubacterium nodatum; C.g. - Capnocytophaga gingivalis; $\mathrm{H}_{2} \mathrm{O}_{2}$ - hydrogen peroxide.

differences in terms of laser type, tip diameter, wavelength, mode of periodontal treatment, number of treated sites, population, and several possible combinations of these parameters. EFP claims that guidelines will change when more evidence becomes available. Further studies will help to define the best protocol of laser application during nonsurgical treatment to achieve long-term effects.

\section{REFERENCES}

1. Mizutani K, Aoki A, Coluzzi D, et al. Lasers in minimally invasive periodontal and peri-implant therapy. J Periodontol 2000. 2016; 71: $185-212$.

2.Dahlen G. Low antibiotic resistance among anaerobic Gram-negative bacteria in periodontitis 5 years following metronidazole therapy. Preus HR. Anaerobe. 2017; 43: 94-98.

3. Reis C, Pacheco JJ, Salazar F, et al. Full-mouth periodontal examination prior to and after nonsurgical treatment in chronic periodontitis patients. Biomed Res. 2016; 27: 406-12.

4. Hill RW, Ramfjord SP, Morrison EC. Four types of periodontal treatment compared over two years. J Periodontol. 1981; 52: 655-62.

5. Lindhe J, Nyman S. The effect of plaque control and surgical pocket elimination on the establishment and maintenance of periodonta health. A longitudinal study of periodontal therapy in cases of advanced disease. J Clin Periodontol. 1975; 2: 67-79.

6. Umeda M, Takeuchi Y, Noguchi K, et al. Effects of nonsurgical periodontal therapy on the microbiota. J Periodontol 2000. 2004; 36: 98-120.

7. Noiri Y, Ebisu S. Identification of periodontal disease associated bacteria in the plaque-free zone. J Periodontol. 2000; 71: 1319-1326.

8. De Almeida JM, Theodoro LH, Bosco AF, et al. In vivo effect of photodynamic therapy on periodontal bone loss in dental furcations. J Clin Periodontol. 2008; 79(6): 1081-8.

9. Samulak- Zielińska R, Dembowska E, Wiernicka-Menkiszak M. System FotoSan w terapii fotodynamicznej chorób przyzębia. Mag Stomatol. 2010; 20(7-8): 49-53.

10. Grzech-Leśniak K, Gaspirc B, Sculean A. Clinical and Microbiological Effects of Multiple Applications of Antibacterial Photodynamic Therapy in Periodontal Maintenance Patients. A Randomized Controlled Clinical Study. Photodiagnosis and Photodynamic Therapy. doi: 10.1016/j.pdpdt.2019.05.028

11.Luan XL, Qin YL, Bi LJ, et al. Histological evaluation of the safety of toluidine bluemediated photosensitization to periodontal tissues in mice Lasers Med Sci. 2009; 24(2): 162-6.

12. Meqa K, Disha M, Dragidella F, et al. Non-surgical periodontal treatment supplemented with photodynamic therapy. J Int Dent Med Res. 2016; 9(3): 139-143.

13. Monzavi A, Chinipardaz Z, Mousavi M, et al. Antimicrobial photodynamic therapy using diode laser activated indocyanine green as an adjunct in the treatment of chronic periodontitis: A randomized clinical trial. Photodiagnosis Photodyn Ther. 2016; 14: 93-97. 
14. Sreedhar A, Indranil S, Padma R, et al. Efficacy of Photodynamic Therapy and Lasers as an Adjunct to Scaling and Root Planing in the Treatment of Aggressive Periodontitis - A Clinical and Microbiologic Short Term Study. J Clin Diagn Res. 2016; 10(2): 8-12.

15. Birang E, Reza M, Ardekani TN. Evaluation of Effectiveness of Photodynamic Therapy With Low-level Diode Laser in Nonsurgical Treatment of Peri-implantitis, Lasers Med Sci. 2017; 8(3): 136-142.

16. Joshi K, Baiju C S, Khashu H, et al. Clinical effectiveness of indocyanine green mediated antimicrobial photodynamic therapy as an adjunct to scaling root planing in treatment of chronic periodontitis - A randomized controlled clinical trial. Photodiagnosis Photodyn Ther. 2020; 29. doi: 10.1016/j.pdpdt.2019.101591

17. Betsy J, Prasanth CS, Baiju KV, et al. Patients' perceptions of antimicrobial photodynamic therapy in the management of chronic periodontitis. Photodiagnosis Photodyn Ther. 2016; 14: 84-90.

18. Vohra F, Akram Z, Bukhan, et al. Short-term effects of adjunctive antimicrobial photodynamic therapy in obese patients with chronic periodontitis: A randomized controlled clinical trial. Photodiagnosis Photodyn Ther. 2018; 21; 10-15.

19. Deumer J, Frentzen M, Meinke MC. Investigation of active matrixmetaloproteinase-8 (aMMP-8) as a reference parameter for path control in antimicrobial photothermal therapy (aPTT) using a split-mouth design. Heliyon. 2019; 5(5). doi: 10.1016/j.heliyon.2019.e01661

20. Al Habashneh R, Mashal MA, Khader Y, et al. Clinical and biological effects of adjunctive photodynamic therapy in refractory periodontitis. J Lasers Med Sci. 2019; 10(2): 139-145. doi: 10.15171/jlms.2019.22

21. Chitsazi, Shirmohammadi M, Shirmohammadi A, Kashefimehr M, et al. Efficacy of Photodynamic Therapy as an Adjunct to Full-mouth Root Planing in the Treatment of Periodontitis Assessed by Real-time PCR: A Microbiological and Clinical Study. Journal of Periodontology \& Implant Dentistry. 2015; 7(1); 26-32.

22. Balata ML, Andrade LP, Santos DBN, et al. Photodynamic therapy associated with full-mouth ultrasonic debridement in the treatment of severe chronic periodontitis: a randomized-controlled clinical trial J Appl Oral Sci. 2013; 21(2): 208-214.

23. Sales de Melo Soares M, Borges C, Invernici M, et al. Antimicrobial photodynamic therapy as adjunct to non-surgical periodontal treatment in smokers: a randomized clinical trial. Clin Oral Investig. 2019; 23: 3173-3182.

24. Arweiler NB, Pietruska M, Skurska A, et al. Nonsurgical treatment of aggressive periodontitis with photodynamic therapy or systemic antibiotics. Three-month results of a randomized, prospective, controlled clinical study. Schweiz Monatsschr Zahnmed. 2013; 123(6): $532-44$.

25. Skurska A, Dolinska E, Pietruska M, et al. Effect of nonsurgical periodontal treatment in conjunction with either systemic administration of amoxicillin and metronidazole or additional photodynamic therapy on the concentration of matrix metalloproteinases 8 and 9 in gingival crevicular fluid in patients with aggressive periodontitis. BMC Oral Health. 2015; 15. doi: 10.1186/s12903-015-0048-0

26. Dörtbudak O, Haas R, Bernhart T, et al. Lethal photosensitization for decontamination of implant surfaces in the treatment of periimplantitis. Clin Oral Implants Res. 2001; 12(2): 104-8.

27. Shibli JA, Martins MC, Ribeiro FS, et al. Lethal photosensitization and guided bone regeneration in treatment of periimplantitis: an experimental study in dogs. Clin Oral Implants Res. 2006; 17(3): 273-81.

28. Grzech-Leśniak K, Sculean A, Gašpirc B. Laser reduction of specific microorganisms in the periodontal pocket using Er:YAG and Nd:YAG lasers: a randomized controlled clinical study. https://doi.org/10.1007/ s10103-018-2491-z

29. Tang E, Arany P. Photobiomodulation and implants: implications for dentistry Periodontal Implant Sci. 2013 Dec; 43(6): 262-268. doi: 10.5051/jpis.2013.43.6.262
30. Grzech-Leśniak K, Belvin Lewis JP, et al. Treatment with Nd: YAG Laser Irradiation Combined with Sodium Hypochlorite or Hydrogen Peroxide Irrigation on Periodontal Pathogens: An In Vitro Study. doi: 10.1089/photob.2019.4775

31. Aoki A, Mizutani K, Schwarz F, et al. Periodontal and peri-implant wound healing following laser therapy. Periodontology 2000; 68(1) 217-269. https://doi.org/10.1111/prd.12080

32. Grzech-Leśniak K, Nowicka J, Pajączkowska M, et al. Effects of Nd:YAG laser irradiation on the growth of Candida albicans and Streptococcus mutans: in vitro study. doi: 10.1007/s10103-018-2622-6

33. Gojkov-Vukelic M, Hadzic S, Dedic A, et al. Application of a Diode Laser in the Reduction of Targeted Periodontal Pathogens. Acta Inform Med. 2013; 21(4): 237-240.

34. Matys J, Jaszczak E, Flieger R, et al. Effect of ozone and diode laser $(635 \mathrm{~nm})$ in reducing orthodontic pain in the maxillary arch-a randomized clinical controlled trial. doi: 10.1007/s10103-019-02896-0

35. Petrovic MS, Kannosh IY, Milasin JM, et al. Clinical, microbiological and cytomorphometric evaluation of low-level laser therapy as an adjunct to periodontal therapy in patients with chronic periodontitis. J Dent Hyg. 2018; 16(2): 120-127.

36. Manjunath S, Singla D, Singh R. Clinical and microbiological evaluation of the synergistic effects of diode laser with nonsurgical periodontal therapy: A randomized clinical trial. J Indian Soc Periodontol 2020; 24: 145-9.

37. Malgikar S, Reddy H, Sagar V, et al. Clinical effects of photodynamic and low-level laser therapies as an adjunct to scaling and root planing of chronic periodontitis: A split-mouth randomized controlled clinical trial. Indian J Dent Res. 2016; 27(2): 121-126.

38. Kachapilly AJ, Majo A, Jayan JM, et al. Management of Chronic Periodontitis Using Chlorhexidine Chip and Diode Laser-A Clinical Study. Journal Clin Diagn Res. 2016; 10(4): 76-80.

39. Meseli SE, Kuru B, Kuru L. Effects of 810-nanometer diode laser as an adjunct to mechanical periodontal treatment on clinical periodontal parameters and gingival crevicular fluid volume of residual periodontal pockets. Nig J Clin Pract. 2017; 20(4): 427-432.

40. Üstün K, Erciyas K, Sezer U, et al. Clinical and biochemical effects of $810 \mathrm{~nm}$ diode laser as an adjunct to periodontal therapy: a randomized split-mouth clinical trial. Photomed Laser Surg. 2014; 32(2): 61-6.

41. Chandra S, Shashikumar P. Diode laser - a novel therapeutic approach in the treatment of chronic periodontitis in type 2 diabetes mellitus patients: a prospective randomized controlled clinical trial. J Lasers Med Sci. 2019; 10(1): 56-63. doi: 10.15171/jlms.2019.09

42. Talmac AC, Calisir M, Regale EG, et al. Effects of Er, Cr: YSGG and Diode Lasers on Clinical Parameters and Gingival Crevicular Fluid IL$1 \beta$ and IL-37 Levels in Generalized Aggressive Periodontitis. Mediators Inflamm. 2019; 2019: 1-9. doi: 10.1155/2019/2780794

43. Al-Falaki R, Francis J. Hughes, Wadia R. Minimally Invasive Treatment of Infrabony Periodontal Defects Using Dual-Wavelength Laser Therapy International Scholarly Research Notices. 2016; 2016. https://doi. org/10.1155/2016/7...

44. Demirturk-Gocgun O, Baser U, Aykol-Sahin G, et al, Issever H, Yalcin F. Role of Low-Level Laser Therapy as an Adjunct to Initial Periodontal Treatment in Type 2 Diabetic Patients: A Split-Mouth, Randomized, Controlled Clinical Trial. Photomed Laser Surg. 2017; 35(2): 111-1.

45. Odor AA, Bechir ES, Forna DA. Effect of Hydrogen Peroxide Photoactivated Decontamination Using $940 \mathrm{~nm}$ Diode Laser in Periodontal Treatment: A Pilot Study. Photobiomodulation, Photomedicine, and Laser Surgery. 2020; 38(10). https://doi.org/10.1089/ photob...

46. Sanz M, Herrera D, Kebschull M, et al on behalf of the EFP Workshop participants and methodological consultants. Treatment of stage I-III periodontitis - The EFP S3 - level clinical practice guideline. J Clin Periodontol. 2020; 47(S22); 4-60. 